\title{
Factors associated with the perception of fear of COVID-19 in university students
}

\author{
Fatores associados à percepção do medo da COVID-19 em estudantes universitários \\ Factores asociados a la percepción de miedo al COVID-19 en estudiantes universitarios
}

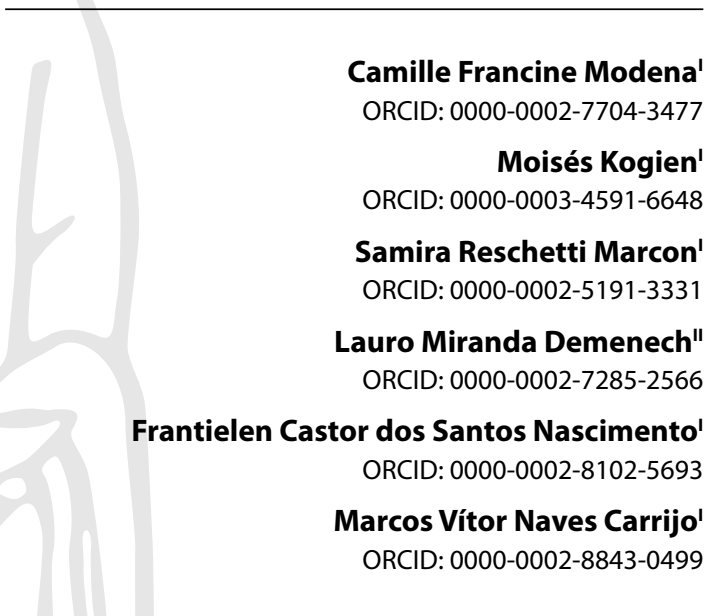

'Universidade Federal de Mato Grosso. Cuiabá, Mato Grosso, Brazil.

"Universidade Federal do Rio Grande. Rio Grande, Rio Grande do Sul, Brazil.

How to cite this article: Modena CF, Kogien M, Marcon SR, Demenech LM Nascimento FCS, Carrijo MVN. Factors associated with the perception of fear of COVID-19 in university students. Rev Bras Enferm. 2022;75(Suppl 1):e20210448. https://doi.org/10.1590/0034-7167-2021-0448

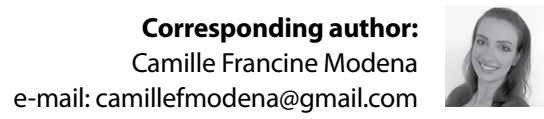

EDITOR IN CHIEF: Álvaro Sousa ASSOCIATE EDITOR: Rafael Silva

Submission: 06-15-202

Approval: 08-14-202

\section{ABSTRACT}

Objective: to analyze the factors associated with the perception of fear of COVID-19 in Brazilian university students. Methods: this is an online, cross-sectional analytical study conducted at a Brazilian public university with 1,437 undergraduate students between September and November 2020. The Fear of COVID-19 Scale was used to measure the main construct. Data analysis was performed using Mann-Whitney $U$ test, Cohen's $r$ test and multiple linear regression analysis. Results: factors associated with fear of COVID-19 in university students were the variables biological sex, perception of good sleep quality, many days of access to information, not complying with social distancing, reporting sufficient hours of sleep, not having a partner, guidance sexual non-heterosexual, being in the risk group for COVID-19 and tobacco consumption. Conclusions: the study findings can contribute to the discussion about the weaknesses that the university population is experiencing in this pandemic period. Descriptors: Fear; COVID-19; Students; University; Risk Factors.

\section{RESUMO}

Objetivo: analisar os fatores associados à percepção de medo da COVID-19 em estudantes universitários brasileiros. Métodos: estudo analítico transversal, online, realizado em uma universidade pública brasileira com 1.437 estudantes de graduação entre setembro e novembro de 2020. Utilizou-se a Escala de Medo da COVID-19 para aferição do construto principal. A análise dos dados se deu pelos testes $U$ de Mann-Whitney, $r$ de Cohen e análise de regressão linear múltipla. Resultados: foram fatores associados ao medo da COVID-19 em estudantes universitários as variávies sexo biológico, percepção de boa qualidade de sono, muitos dias de acesso a informações, não cumprir distanciamento social, relato de horas suficientes de sono, não possuir companheiro(a), orientação sexual não heterossexual, ser do grupo de risco para COVID-19 e consumo tabaco. Conclusões: os achados do estudo podem contribuir para a discussão sobre as fragilidades que a população universitária está vivenciando neste período pandêmico.

Descritores: Medo; COVID-19; Estudantes; Universidade; Fatores de Risco.

\section{RESUMEN}

Objetivo: analizar los factores asociados a la percepción del miedo al COVID-19 en estudiantes universitarios brasileños. Métodos: estudio analítico transversal en línea realizado en una universidad pública brasileña con 1.437 estudiantes de pregrado entre septiembre y noviembre de 2020. Se utilizó la Escala de Miedo COVID-19 para medir el constructo principal. El análisis de los datos se realizó mediante la prueba $U$ de Mann-Whitney, la prueba $r$ de Cohen y el análisis de regresión lineal múltiple. Resultados: Ios factores asociados al miedo al COVID-19 en estudiantes universitarios fueron las variables sexo biológico, percepción de buena calidad del sueño, muchos días de acceso a la información, no cumplir con el distanciamiento social, reportar suficientes horas de sueño, no tener pareja, orientación. sexual no heterosexual, estar en el grupo de riesgo de COVID-19 y consumo de tabaco. Conclusiones: los hallazgos del estudio pueden contribuir a la discusión sobre las debilidades que vive la población universitaria en este período pandémico.

Descriptores: Miedo; COVID-19; Estudiantes; Universidad; Factores de Riesgo. 


\section{INTRODUCTION}

At the end of 2019, the first human cases of COVID-19 (Coronavirus Disease 2019), a disease caused by SARS-CoV-2 (Severe Acute Respiratory) were identified in the city of Wuhan, China. Coronavirus 2 Syndrome) $)^{(1)}$, an etiological agent with rapid dissemination and high potential for contagion, which generated an exponential increase in the number of cases $^{(2)}$. Coronaviruses (CoVs) are a large family of viruses, several of which cause respiratory illnesses in humans, from the common cold to more rare and serious illnesses ${ }^{(1)}$.

Due to its rapid expansion around the world, the World Health Organization (WHO) officially characterized the COVID-19 outbreak as a pandemic state in March 2020, treating it as a serious threat to public health, with all nations facing unique challenges ${ }^{(3)}$. The decree of the state of pandemic by COVID-19 brought a series of repercussions to people's lives, drastically changing their daily lives and the way of relating to others and to the environment ${ }^{(4)}$. Such changes ended up having deleterious repercussions in various facets of human life, especially in individuals' mental health ${ }^{(5)}$, including university students, who had their activities interrupted or considerably modified, mainly due to the severity of the pandemic and the need to adopt measures of social distancing and isolation ${ }^{(6)}$.

This scenario of uncertainties, threat perception and changes in daily life can potentially reverberate in fear of the disease ${ }^{(7-8)}$. Fear of COVID-19 has been characterized as an important predictor of behavioral changes and health protection as well as harmful outcomes to people's well-being. Specifically in university students, greater fear of COVID-19 has been associated with a higher prevalence of symptoms of anxiety ${ }^{(9)}$, depression ${ }^{(10)}$ and even suicidal behavior ${ }^{(11)}$. This fact denotes a greater vulnerability of this population, probably because their academic demands are highly impacted by the pandemic, which generated uncertainties and imposed a series of new challenges to the training processes ${ }^{(12)}$, marked by distance learning and its weaknesses, recommendations for isolation and social distancing that change interpersonal relationships at the university and can thus trigger considerably negative impacts on university students' lives ${ }^{(13)}$.

In the pandemic context, university students have shown indicators of moderate to high prevalence of fear of COVID-19(12), which may contribute to the increased load of stress and mental distress among this population ${ }^{(14)}$. However, despite this finding, there is still little evidence on which elements or characteristics are associated with the intensity of perceived fear of COVID-19 both in the general population ${ }^{(15)}$ and among university students, highlighting the need for further investigations to fulfill this gap. Knowledge of factors associated with greater or lesser perception of fear of COVID-19 can be particularly useful, especially for university managers and healthcare professionals, in the development of effective educational and/or health policies that mitigate the negative psychological impact on the mental health and academic performance of university students ${ }^{(14)}$.

\section{OBJECTIVE}

To analyze the factors associated with the perception of fear of COVID-19 in Brazilian university students.

\section{METHODS}

\section{Ethical aspects}

This study was approved by the Institutional Review Board of the Universidade Federal do Mato Grosso (UFMT) and complied with all current national regulations, ensuring confidentiality, anonymity and non-maleficence of participants, in accordance with Resolution 466/2012 $2^{(16)}$.

\section{Study design, place, and period}

This is an analytical cross-sectional study, carried out at a public university in the Brazilian Midwest, between September and November 2020, during the spread of the COVID-19 pandemic. The study design was guided by the STROBE guidelines (Strengthening the Reporting of Observational Studies in Epidemiology) ${ }^{(17)}$.

\section{Population, sample, and eligibility criteria}

The study was carried out with undergraduate students over 18 years of age and who were regularly enrolled during the period of data collection.

To estimate the sample size, the formula proposed by Espinosa et al. ${ }^{(18)}$, population of 16,152 undergraduate students distributed in four university campuses, 95\% confidence coefficient, $2.6 \%$ sampling error, and $50 \%$ outcome proportion were considered as a parameter. The proposed procedure was also used to ensure a coverage percentage of $85 \%^{(19)}$, in order to mitigate the effects of losses due to missing data. Thus, a sample of 1,536 students from all campuses was estimated. Having completed the proposed period for data collection, a total of 1,746 respondents were obtained, and, from this total, 309 questionnaires were excluded due to the presence of missing data, which resulted in a final sample of 1,437 students, corresponding to coverage of $93.5 \%$ of the pre-defined sample.

\section{Study protocol}

The survey was conducted on the Research Electronic Data Capture (REDCap) online platform. The University's Department of Information Technology (STI) sent the research link with the instruments, study objectives and contact of those responsible for all undergraduate students. After 30 days from the beginning of the collection, the STI sent another reminder, as a reminder, to those students who had not yet responded and were interested in participating. The questionnaire used in this study was confidential and self-administered, consisting of a specific instrument for the general characterization of the sample and a validated instrument for measuring fear of COVID-19.

To characterize the sample, a self-report questionnaire was used, developed specifically for the context of the study and divided into sections that included social (biological gender, age, self-reported skin color, marital status, sexual orientation and religious belief), behavioral (use of alcohol, tobacco and/ or marijuana, subjective perceptions of quality and quantity of sleep) and contextual characteristics to the COVID-19 pandemic (fulfilling social distancing, diagnosis of COVID-19, belonging to the risk group and access to information pandemic-specific). 
To assess fear of COVID-19, the Fear of COVID-19 Scale(20) was used, which contains seven items with 5-point Likert responses ( 1 to 5 ). The total score ranges from 7 to 35 points, being classified as "little fear" (7 to 19), "moderate fear" (20 to 26) and "very afraid" (above 27). This scale was translated and validated for the Brazilian context, having presented good psychometric performance ${ }^{(21)}$. In this study, the internal consistency (Cronbach's alpha) was 0.86 .

\section{Statistical analysis}

Bivariate comparative analyzes between the mean COVID-19 fear scores were performed between the different groups analyzed using the Mann-Whitney $U$ test for independent samples, adopting a significance level of $95 \%$. The magnitude of the effect was calculated using Cohen's $r$ test, obtained by dividing the value of $Z$ by the square root of the sample size $(r=Z / \sqrt{ } N)^{(22)}$. In interpreting the magnitude of the effect, effects between 0.00 and 0.10 were considered as negligible or null, between 0.11 and 0.29 , weak, between 0.30 and 0.49 , moderate effects and greater than 0.50 , strong effects $^{(23)}$.

Associated factors were identified, using a multiple linear regression model, to verify the ability of explanatory variables to predict the intensity of fear perception of COVID-19. For the construction of the multiple model, the social, behavioral and related determinants of coping with the pandemic are considered, which presented a $\mathrm{p}$-value $<0.20$ in bivariate analysis. These variables were introduced, individually, in the model by the enter method, following ascending order of significance magnitude of the effect, with the variables that presented a value of $p<0.05$ remaining in the final model. It is noteworthy that, before the adoption of multiple linear regression modeling, the assumptions of normality of distribution of residuals, absence of multicollinearity (Variance Inflation Factor [VIF] < 10) and verification of non-occurrence of autocorrelation of residues (Durbin-Watson $=2,031$ ).

The Mann-Whitney $U$ test and multiple linear regression analysis were performed using the Statistical Package for the Social Sciences (SPSS), version 23.0, while Microsoft Excel for Windows was used to calculate the effect size.

\section{RESULTS}

The sample of this study consisted of 1,437 students from different university campuses at the Universidade Federal do Mato Grosso(UFMT). Regarding the fear of COVID-19. the sample had a mean score of 20.78 points, consistent with moderate fear of the disease (Table 1), a total of 600 students (41.8\%) had scores compatible with moderate fear of the disease.

For the differences in the average fear scores of COVID-19 according to the social characteristics of the university students, there were significant differences in the average fear score according to biological sex, marital status and sexual orientation. It is noteworthy that the largest effect size was presented by the biological sex variable $(r=0.26)$ (Table 2$)$.
Table 1 - Characterization of fear of COVID-19 in a sample of Brazilian university students $(n=1437)$, Cuiabá, Mato Grosso, Brazil, 2020

\begin{tabular}{lcc}
\hline Fear perception classification & RR & $\mathbf{9 5 \%} \mathbf{C l}$ \\
\hline Little fear $(\mathrm{n}=570)$ & $39.7 \%$ & $37.2-42.2$ \\
Moderate fear $(\mathrm{n}=600)$ & $41.8 \%$ & $39.1-44.4$ \\
Very scared $(\mathrm{n}=267)$ & $18.6 \%$ & $16.6-20.8$ \\
& Mean score & Standard deviation \\
Fear of COVID-19 & 20.78 & \pm 6.283 \\
\hline $95 \%$ Cl:95\% confidence interval & &
\end{tabular}

95\% Cl: 95\% confidence interval.

Table 2 - Comparison between social characteristicsand mean fear scores of COVID-19 among Brazilian university students ( $n=1437)$, Cuiabá, Mato Grosso, Brazil, 2020

\begin{tabular}{|c|c|c|c|c|}
\hline $\begin{array}{l}\text { Sociodemographic } \\
\text { characteristics }\end{array}$ & $\begin{array}{l}\text { Mean score } \\
\text { (standard } \\
\text { deviation) }\end{array}$ & $\mathbf{Z}$ & $p$ value & $r$ \\
\hline $\begin{array}{l}\text { Biological sex } \\
\quad \text { Male }(n=483) \\
\text { Female }(n=954)\end{array}$ & $\begin{array}{l}18.33( \pm 6.544) \\
20.29( \pm 6.767)\end{array}$ & \multicolumn{2}{|c|}{$-10.170<\mathbf{0 . 0 0 1}$} & 0.26 \\
\hline $\begin{array}{l}\text { Median age }(22 \text { years }) \\
\quad<22 \text { years old }(n=797) \\
\quad \geq 22 \text { years old }(n=640)\end{array}$ & $\begin{array}{l}20.74( \pm 6.139) \\
20.83( \pm 6.463)\end{array}$ & -0.196 & 0.844 & 0.01 \\
\hline $\begin{array}{l}\text { Self-reported skin color } \\
\text { White }(n=587) \\
\text { None-white }(n=850)\end{array}$ & $\begin{array}{l}20.69( \pm 6.106) \\
20.84( \pm 6.406)\end{array}$ & -0.684 & 0.494 & 0.02 \\
\hline $\begin{array}{l}\text { Marital status } \\
\text { With partner }(n=655) \\
\text { No partner }(n=782)\end{array}$ & $\begin{array}{l}21.26( \pm 6.158) \\
20.37( \pm 6.362)\end{array}$ & -2.702 & 0.007 & 0.07 \\
\hline $\begin{array}{l}\text { Sexual orientation } \\
\text { Heterosexual }(n=1028) \\
\text { Non-heterosexual }(n=409)\end{array}$ & $\begin{array}{l}20.30( \pm 6.236) \\
21.97( \pm 6.253)\end{array}$ & -4.477 & $<0.001$ & 0.12 \\
\hline $\begin{array}{l}\text { Religious belief } \\
\text { Yes }(n=985) \\
\text { No }(n=452)\end{array}$ & $\begin{array}{l}20.90( \pm 6.190) \\
20.50( \pm 6.481)\end{array}$ & -1.203 & 0.229 & 0.03 \\
\hline
\end{tabular}

Table 3 - Comparison between substance use behavior, sleep and COVID-19 mean fear scores among Brazilian university students ( $n=1437)$, Cuiabá, Mato Grosso, Brazil, 2020

\begin{tabular}{|c|c|c|c|c|}
\hline $\begin{array}{l}\text { Behavioral } \\
\text { characteristics }\end{array}$ & $\begin{array}{c}\text { Mean score } \\
\text { (standard } \\
\text { deviation) }\end{array}$ & $\mathbf{Z}$ & $p$ value & $\mathbf{r}$ \\
\hline \multicolumn{5}{|l|}{ Alcohol consumption } \\
\hline Yes $(n=770)$ & $21.20( \pm 6.159)$ & \multirow{2}{*}{-2.467} & \multirow{2}{*}{0.014} & \multirow{2}{*}{0.07} \\
\hline No $(n=667)$ & $20.29( \pm 6.394)$ & & & \\
\hline \multicolumn{5}{|l|}{ Tobacco consumption } \\
\hline Yes $(n=175)$ & $21.67( \pm 6.827)$ & \multirow{2}{*}{-2.059} & \multirow{2}{*}{0.039} & \multirow{2}{*}{0.05} \\
\hline No $(n=1262)$ & $20.65( \pm 6.197)$ & & & \\
\hline \multicolumn{5}{|l|}{ Marijuana consumption } \\
\hline Yes $(n=148)$ & $21.30( \pm 6.099)$ & \multirow{2}{*}{-0.274} & \multirow{2}{*}{0.274} & \multirow{2}{*}{0.01} \\
\hline No $(n=1289)$ & $20.72( \pm 6.304)$ & & & \\
\hline \multicolumn{5}{|l|}{$\begin{array}{l}\text { Increased alcohol consumption during } \\
\text { the pandemic }\end{array}$} \\
\hline No increase $(n=616)$ & $20.96( \pm 6.125)$ & \multirow{2}{*}{-2.267} & \multirow{2}{*}{0.023} & \multirow{2}{*}{0.08} \\
\hline With increase $(n=154)$ & $22.16( \pm 6.224)$ & & & \\
\hline \multicolumn{5}{|l|}{$\begin{array}{l}\text { Increased tobacco use during the } \\
\text { pandemic }\end{array}$} \\
\hline No increase $(n=132)$ & $21.24( \pm 6.874)$ & \multirow{2}{*}{-1.492} & \multirow{2}{*}{0.136} & \multirow{2}{*}{0.11} \\
\hline With increase $(n=43)$ & $23.05( \pm 6.572)$ & & & \\
\hline \multicolumn{5}{|l|}{$\begin{array}{l}\text { Increased marijuana use during the } \\
\text { pandemic }\end{array}$} \\
\hline No increase $(n=122)$ & $21.72( \pm 5.956)$ & \multirow{2}{*}{-1.605} & \multirow{2}{*}{0.109} & \multirow{2}{*}{0.13} \\
\hline With increase $(n=26)$ & $19.31( \pm 6.485)$ & & & \\
\hline \multicolumn{5}{|l|}{$\begin{array}{l}\text { Subjective assessment of sleep quality } \\
\text { during the pandemic }\end{array}$} \\
\hline No perception of worsening $(n=719)$ & $18.90( \pm 5.949)$ & \multirow{2}{*}{-11.447} & \multirow{2}{*}{$<0.001$} & \multirow{2}{*}{0.30} \\
\hline With perception of worsening $(n=718)$ & $22.66( \pm 6.047)$ & & & \\
\hline \multicolumn{5}{|l|}{$\begin{array}{l}\text { Subjective assessment of the amount } \\
\text { of sleep hours }\end{array}$} \\
\hline No change $(n=421)$ & $19.01( \pm 6.019)$ & \multirow{2}{*}{-6.779} & \multirow{2}{*}{$<0.001$} & \multirow{2}{*}{0.18} \\
\hline With change $(n=1016)$ & $21.51( \pm 6.247)$ & & & \\
\hline
\end{tabular}


Table 4 - Comparison between contextual characteristics to the pandemic and mean COVID-19 fear scores among Brazilian university students $(\mathrm{n}=$ 1,437), Cuiabá, Mato Grosso, Brazil, 2020

\begin{tabular}{|c|c|c|c|c|}
\hline $\begin{array}{l}\text { Contextual characteristics } \\
\text { to the pandemic }\end{array}$ & $\begin{array}{l}\text { Mean score } \\
\text { (standard } \\
\text { deviation) }\end{array}$ & $\mathbf{Z}$ & $p$ value & $r$ \\
\hline $\begin{array}{l}\text { Comply with social distancing } \\
\text { Yes }(n=910) \\
\text { No }(n=527)\end{array}$ & $\begin{array}{l}21.28( \pm 6.124) \\
19.90( \pm 6.463)\end{array}$ & -3.875 & $5<0.001$ & 0.10 \\
\hline $\begin{array}{l}\text { COVID-19 diagnosis } \\
\text { Yes }(n=325) \\
\text { No }(n=1112)\end{array}$ & $\begin{array}{l}20.76( \pm 5.906) \\
20.78( \pm 6.392)\end{array}$ & -0.096 & $5 \quad 0.924$ & 0.00 \\
\hline $\begin{array}{l}\text { Risk group for COVID-19 } \\
\text { Yes }(n=446) \\
\text { No }(n=991)\end{array}$ & $\begin{array}{l}21.83( \pm 6.553) \\
20.30( \pm 6.102)\end{array}$ & -4.104 & $4<0.001$ & 0.11 \\
\hline $\begin{array}{l}\text { Access to pandemic-related } \\
\text { information during the week } \\
\text { Few days of access }(n=819) \\
\text { Many days of access }(n=618)\end{array}$ & $\begin{array}{l}20.03( \pm 6.237) \\
21.76( \pm 6.214)\end{array}$ & -5.144 & $4<0.001$ & 0.14 \\
\hline
\end{tabular}

Differences between mean fear scores of COVID-19 were also assessed according to behavioral characteristics of the sample of university students. Significant differences in fear of COVID-19 were found among students who consumed alcohol and tobacco, and among those who used alcohol, there was a difference between those who increased their consumption during the pandemic state when compared with those who did not increase their consumption of alcohol. Subjective assessments of the quality and quantity of sleep hours were also used, finding significant differences between the groups with a perception of worsening sleep quality and with changes in the number of hours of sleep. Among the groups with significant differences, the effect size found was moderate only for the variable "subjective sleep quality assessment" $(r=0.30)$ (Table 3 ).

Specific characteristics related to the experience of the current pandemic context were also compared with the mean COVID-19 fear scores reported by university students, with significantly higher fear scores being found among those who complied with the measures of social distancing, who were a risk group for COVID -19 or who reported many days of access to pandemic-related information during the week (Table 4).
Table 5 shows the variables that remained associated with fear of COVID-19 after multiple linear regression, highlighting that the results of the final model adopted were significant $[F$ $(9,1427)=40.129 ; p<0.001 ; R 2=0.202$ ] and indicate that about $20 \%$ of the variance of the COVID-19 fear variable was explained by the set of selected variables.

The biological sex variable was the one with the greatest explanatory power $[\beta=0.239 ; t=9,875 ; p<0.001]$, demonstrating that being female increased, on average, 3176 points in the COVID-19 fear scale score. They were also factors associated with fear of COVID-19. the subjective perception of worsening sleep quality during the pandemic $[\beta=0.199 ; t=7,258 ; p<0.001]$, many days of information access $[\beta=0.120 ; t=5066 ; p<0.001]$, not complying with social distance $[\beta=-0.104 ; t=-4347 ; p<0.001]$, the subjective perception of change in sleep hours during the pandemic $[\beta=0.100$; $\mathrm{t}=3678 ; \mathrm{p}<0.001]$, not having a partner $[\beta=-0.078 ; \mathrm{t}=-3,218 ; \mathrm{p}=$ $0.001]$, non-heterosexual sexual orientation $[\beta=0.073 ; t=2989 ; p=$ $0.003]$, being from the risk group for COVID-19 $[\beta=0.065 ; \mathrm{t}=2729$; $p=0.006]$ and tobacco use $[\beta=0.063 ; t=2,592 ; p=0.010]$.

\section{DISCUSSION}

This study assessed the perception of fear of COVID-19 and associated factors in a sample of Brazilian university students. The findings showed that the highest percentage of university students assessed (41.8\%) perceived themselves as having moderate fear of COVID-19. Fear is an adaptive response that generally occurs when exposed to a potentially dangerous situation and has been one of the psychological reactions most frequently experienced by the population during the COVID-19 pandemic ${ }^{(7)}$, constituting a unique experience permeated by idiosyncrasies, affecting people and social groups in different ways.

Analysis of social variables showed that female students had, in general, significantly higher mean scores with the experience of moderate fear, when compared to men. Gender differences and women's greater vulnerability to fear of COVID-19 have been a recurrent finding in the international literature in the current pandemic context $^{(12,24-26)}$. It is believed that, during the pandemic, women have experienced greater physical and psychosocial overload, since, in

Table 5 - Multiple linear regression analysis of factors associated with fear of COVID-19 in Brazilian university students ( $n=1437)$, Cuiabá, Mato Grosso, Brazil, 2020

\begin{tabular}{|c|c|c|c|c|c|c|c|}
\hline \multirow{3}{*}{$\begin{array}{l}\text { Variables } \\
\text { (reference category) }\end{array}$} & \multicolumn{3}{|c|}{ Multiple linear regression analysis } & \multirow{3}{*}{$95 \% \mathrm{Cl}$} & \multirow{3}{*}{$\mathbf{t}$} & \multirow{3}{*}{$p$ value } & \multirow{3}{*}{ VIF } \\
\hline & \multicolumn{2}{|c|}{$\begin{array}{c}\text { Coefficients } \\
\text { non-standard }\end{array}$} & \multirow{2}{*}{$\begin{array}{c}\text { Standardized } \\
\text { coefficient } \\
\text { B }\end{array}$} & & & & \\
\hline & B & Standard error & & & & & \\
\hline Intercept & 16.273 & 0.412 & & $15.465 ; 17.080$ & 39.529 & $<0.001$ & \\
\hline Biological sex (female) & 3.176 & 0.322 & 0.239 & $2.545 ; 3.807$ & 9.875 & $<0.001$ & 1.046 \\
\hline Sleep quality (worsening) & 2.498 & 0.344 & 0.199 & $1.823 ; 3.173$ & 7.258 & $<0.001$ & 1.342 \\
\hline Access to information (many days of access) & 1.523 & 0.301 & 0.120 & $0.934 ; 2.113$ & 5.066 & $<0.001$ & 1.005 \\
\hline Social distancing (not comply) & -1.351 & 0.311 & -0.104 & $-1.961 ;-0.741$ & -4.347 & $<0.001$ & 1.017 \\
\hline Amount of sleep (change in the amount of hours) & 0.862 & 0.234 & 0.100 & $0.402 ; 1.322$ & 3.678 & $<0.001$ & 1.321 \\
\hline Marital status (without a partner) & -0.978 & 0.304 & -0.078 & $-1.574 ;-0.382$ & -3.218 & 0.001 & 1.038 \\
\hline Sexual orientation (non-heterosexual) & 1.019 & 0.341 & 0.073 & $0.350 ; 1.688$ & 2.989 & 0.003 & 1.073 \\
\hline Group of risk (yes) & 0.887 & 0.325 & 0.065 & $0.250 ; 1.525$ & 2.729 & 0.006 & 1.025 \\
\hline Tobacco consumption (yes) & 0.911 & 0.352 & 0.063 & $0.221 ; 1.601$ & 2.592 & 0.010 & 1.056 \\
\hline
\end{tabular}


addition to caring for children and older adults, they also mostly take over responsibilities with domestic activities, often while managing professional and academic life demands. Also, the repercussions of dealing with demands from multiple social roles and their innate stressors in a distinct context such as the COVID-19 pandemic alone can result in negative personal and structural impacts on females. There are also situations that are aggravated by the experience of additional phenomena that are peculiarly manifested in times of global health crisis, with greater frequency of reports of victimization by domestic violence ${ }^{(27)}$, the fear of the illness itself or the illness of people close to whom the women are responsible for the care. Somatically, all these elements can arouse the feeling of greater perception of fear and vulnerability to COVID-19 among females.

Marital status was also significantly associated with fear of COVID-19, showing that lower fear scores were presented by students who reported not having a partner in a marital relationship. Although the similar relationship between marital status and fear of COVID-19 was found in a study with American university students, explanations for such association are still unclear ${ }^{(28)}$. It is known that good quality marital relationships have, in general, a positive effect on physical and mental health as well as on coping with stressful experiences/situations in the pre-pandemic scenario ${ }^{(29,30)}$. However, in the context of the COVID-19 pandemic, it is assumed that having a partner can be characterized as a potentially anxiogenic experience, since, in addition to worrying about their own risk of contamination and illness, students become concerned with the well-being and health of their partner ${ }^{(28)}$.

It was also evidenced that students with a non-heterosexual orientation (homosexual, bisexual, asexual or pansexual) had higher fear scores of COVID-19 when compared to their heterosexually oriented peers. The non-heterosexual population, as well as other minority groups, suffers from an additional load of stressors that puts them at greater probability of harmful physical and mental health outcomes, including the perception of greater fear of COVID-19, as they feel more vulnerable to the disease ${ }^{(31)}$. Socioeconomic vulnerability, exposure to various forms of interpersonal violence, stigmatization, prejudice and social exclusion are examples of additional stressors to which the non-heterosexual population is exposed ${ }^{(32)}$ and which can result in the perception of greater fear during the pandemic.

In the analysis of behavioral variables, this study included behaviors related to substance use and sleep. It was observed that students who reported tobacco use had higher fear scores of COVID-19, when compared to those who were abstainers of this substance. Although not consensual, there is a hypothesis that smokers are vulnerable to a greater risk of suffering more severe complications from COVID-19. Tobacco use affects and injures lung tissue, increasing the risk of lung injury, which can facilitate the invasion of lung tissue by the coronavirus, causing more severe symptoms and increasing the risk of death ${ }^{(33)}$. This possibility of increased risk of death and/or complications from a little-known disease can lead to fear and distress among smoking students, given that smoking is a behavior whose prevalence tends to increase during university experience ${ }^{(34)}$.

Regarding sleep, students who reported a perception of worsening sleep quality during the pandemic had higher indicators of fear of COVID-19, when compared to their peers who did not notice any change in their sleep pattern. In addition to the worsening of sleep quality, the greatest fear of COVID-19 was also significantly observed among students with changes in the amount of sleep hours, compared to those who did not notice changes. The negative impact of the COVID-19 pandemic on sleep quality has been observed in several studies ${ }^{(35-37)}$. Feelings such as fear and social isolation, common in the pandemic context, can act to increase serum cortisol levels and reduce melatonin synthesis, resulting in changes in biological rhythms and dysregulation of the hypothalamic-pituitary-adrenal axis that result in changes in chronotype and perceptions of poor sleep ${ }^{(35,37)}$. This evidence is particularly noteworthy for the university population, which, even in pre-pandemic contexts, had a high prevalence of sleep disorders with serious repercussions on academic performance ${ }^{(38)}$.

Analysis of contextual variables related to the pandemic showed that students who reported not complying with social distancing had lower indicators of fear of COVID-19, compared to students who reported complying with/adopting these measures. Studies on the appeal to fear have demonstrated the importance of this construct as an encouraging element for the adoption of adaptive health promotion behaviors ${ }^{(15,39)}$. Including, showing that individuals who feel fear more efficiently comply with social distancing to avoid infection by the disease, thus taking preventive measures more rigorously ${ }^{(39)}$.

Students who reported belonging to the risk group for $\mathrm{CO}$ VID-19 had a higher mean score of fear of COVID-19. This finding was consistent with what has been shown in the literature, which demonstrates that individuals in the risk group for COVID-19, as they have chronic conditions and comorbidities, they report more often intense levels of concerns and fears related to the disease, mainly due to problems of a psychological nature ${ }^{(25,40)}$. Considering the severe course of the disease and the high mortality rates among people in the risk group, it is expected that they show a high fear of contracting the disease.

Many days of access to information was also a factor associated with greater fear of COVID-19 among university students in this sample. Access to information is a useful and necessary tool in a pandemic scenario that helps to reduce the spread and circulation of the virus. However, overexposure to information related to a stressful event can have negative effects and result in increased levels of fear and prolonged experiences of acute stress $^{(41)}$. Evidence from previous health crises, such as the H5N1 avian flu outbreak, found that greater exposure to social media was directly related to the increased perception of fear at that time ${ }^{(42)}$. In the current COVID-19 pandemic, the phenomenon of "infodemic" has gained prominence and relevance, with an exponential volume of information being disseminated day after day, much of which is not always true and that arises with dubious intent. This information overload can result in fear, anxiety and symptoms of exhaustion, mainly due to the inability of people to assimilate all this volume of data ${ }^{(43)}$.

\section{Study limitations}

It is important to highlight that, in cross-sectional studies, the relationship between exposure and outcome is assessed at the same time, which makes it impossible to establish a causal 
relationship. Furthermore, the investigated sample is from a single population, which may restrict representation for different contexts. Still, studies with self-administered questionnaires, even if validated and widely used, present difficulties to control data loss.

\section{Contributions to nursing}

Fear related to the COVID-19 pandemic can negatively impact students' mental and emotional health as well as reverberate in academic life, compromising performance and performance. Thus, knowing the determinants that contribute to increasing the fear of the disease can help healthcare professionals, including nurses, to propose targeted actions to mitigate the negative effects caused by this situation, in addition to allowing the tracking of students who may benefit from early social and/or psychological assistance.

Moreover, the results obtained can support university managers in planning academic policies aimed at assisting students with greater vulnerability to fear of COVID-19, aiming to minimize the distress experienced during the training process in this pandemic period.

\section{CONCLUSIONS}

A high percentage of college students with moderate or severe fear related to COVID-19 was observed, with the intensity of perception of this construct, if associated with social, behavioral and contextual characteristics related to the pandemic.

In the present study, fear of COVID-19 was influenced by factors associated with the female gender, the perception of worsening sleep quality during the pandemic, many days of access to information about the pandemic, not complying with social distancing, reporting insufficient hours of sleep, not having a partner, non-heterosexual sexual orientation, being in the risk group for COVID-19 and consuming tobacco.

\section{ACKNOWLEDGMENTS}

We would like to thank the students who participated in the research, NESM members (Center for Studies in Mental Health), who helped in the dissemination, and the University's Dean of Undergraduate Education (PROEG) for their support in carrying out the study.

\section{REFERENCES}

1. World Health Organization (WHO). Origin of SARS-CoV-2 [Internet]. Geneva:WHO; 2020[cited 2021 Mar 22]. Available from: https://apps. who.int/iris/bitstream/handle/10665/332197/WHO-2019-nCoVFAQ-Virus_origin-2020.1-eng.pdf

2. Malta DC, Szwarcwald CL, Barros MBA, Gomes CS, Machado ÍE, Souza Jr PRB, el al. The covid-19 pandemic and changes in adult Brazilian lifestyles: a cross-sectional study, 2020. Epidemiol Serv Saude. 2020;29(4):e2020407. https://doi.org/10.1590/s1679-49742020000400026

3. World Health Organization (WHO). Coronavirus disease (covid-19) pandemic [Internet]. Geneva: WHO; 2021 [cited 2021 Mar 22]. Available from: https://www.who.int/emergencies/diseases/novel-coronavirus-2019

4. Sher L. The impact of the covid-19 pandemic on suicide rates. QJM. 2020;113(10):707-12. https://doi.org/10.1093/qjmed/hcaa202

5. Brooks SK, Webster RK, Smith LE, Woodland L, Wessely S, Greenberg N, et al. The psychological impact of quarantine and how to reduce it: rapid review of the evidence. Lancet. 2020;395(10227):912-920. https://doi.org/10.1016/S0140-6736(20)30460-8

6. United Nations Educational, Scientific and Cultural Organization. Covid-19 educational disruption and response [Internet]. Paris: Unesco; 2020[cited 2020 Dec 14]. Available from: http://www.iiep.unesco.org/en/covid-19-educational-disruption-and-response13363

7. Arora A, Jha AK, Alat P, Das SS. Understanding coronaphobia. Asian J Psychiatr. 2020;54:102384. https://doi.org/10.1016/j.ajp.2020.102384

8. Li R. Fear of covid-19: what causes fear and how individuals cope with it. Health Commun. 2021:1-10. https://doi.org/10.1080/10410236.202 1.1901423

9. Mertens G, Gerritsen L, Duijndam S, Salemink E, Engelhard IM. Fear of the coronavirus (covid-19): predictors in an online study conducted in march 2020. J Anxiety Disord. 2020;74:102258. https://doi.org/10.1016/j.janxdis.2020.102258

10. Fruehwirth JC, Biswas S, Perreira KM. The covid-19 pandemic and mental health of first-year college students: examining the effect of covid-19 stressors using longitudinal data. PLoS One. 2021:16(3):e0247999. https://doi.org/10.1371/journal.pone.0247999

11. Goyal P, Choi JJ, Pinheiro LC, Schenck EJ, Chen R, Jabri A, et al. Clinical characteristics of covid-19 in New York city. N Engl J Med. 2020;382(24):2372-4. https://doi.org/10.1056/NEJMc2010419

12. Rodríguez-Hidalgo AJ, Pantaleón Y, Dios I, Falla D. Fear of covid-19, stress, and anxiety in university undergraduate students: a predictive model for depression. Front Psychol. 2020;11:591797. https://doi.org/10.3389/fpsyg.2020.591797

13. Son C, Hegde S, Smith A, Wang X, Sasangohar F. Effects of covid-19 on college students' mental health in the United States: interview survey study. J Med Internet Res. 2020;22(9):e21279. https://doi.org/10.2196/21279

14. Browning MHEM, Larson LR, Sharaievska I, Rigolon A, McAnirlin O, Mullenbach L, et al. Psychological impacts from covid-19 among university students: risk factors across seven states in the United States. PLoS ONE. 2021;16(1):e0245327. https://doi.org/10.1371/journal. pone. 0245327

15. Eder SJ, Steyrl D, Stefanczyk MM, Pieniak M, Martínez Molina J, Pešout O, et al. Predicting fear and perceived health during the covid-19 pandemic using machine learning: a cross-national longitudinal study. PLoS One. 2021;16(3):e0247997. https://doi.org/10.1371/journal. pone.0247997 
16. Ministério da Saúde (BR). Resolução n 466, de 12 de dezembro de 2012. Conselho Nacional de Saúde. Diretrizes e normas regulamentadoras de pesquisas envolvendo seres humanos. Brasília, DF: MS; 2012.

17. Von Elm E, Altman DG, Egger M, Pocock SJ, Gøtzsche PC, Vandenbroucke JP. Strengthening the reporting of observational studies in epidemiology (STROBE) statement: guidelines for reporting observational studies. BMJ. 2007;335:806-8. https://doi.org/10.1136/ bmj.39335.541782.AD

18. Martinez Espinosa M, Bieski IGC, Martins DTO. Probability sampling design in ethnobotanical surveys of medicinal plants. Rev Bras Farmacogn. 2012;22(6):1362-7. https://doi.org/10.1590/S0102-695X2012005000091

19. Martinez Espinosa M, Rezende AC, Castelo LM, Moura, MVD. Uma medida empírica para reduzir o vício no planejamento de amostragem aleatória simples e estratificada causado pela ausência de resposta. Sigmae [Internet]. 2019[cited 2021 Mar 22];8(2):722-7. https:// publicacoes.unifal-mg.edu.br/revistas/index.php/sigmae/article/view/945/691

20. Ahorsu DK, Lin C-Y, Imani V, Saffari M, Griffiths MD, Pakpour AH. The fear of covid-19 scale: development and initial validation. Int J Ment Health Addict. 2020:1-9. https://doi.org/10.1007/s11469-020-00270-8

21. Peres RS, Frick LT, Queluz FNFR, Fernandes SCS, Priolo-Filho SR, Stelko-Pereira AC, et al. Evidências de validade de uma versão brasileira da fear of covid-19 scale. Cienc Saude Colet. 2021;26(8):3255-64. https://doi.org/10.1590/1413-81232021268.06092021

22. Fritz CO, Morris PE, Richler JJ. Effect size estimates: current use, calculations, and interpretation. J Exp Psychol Gen. 2012;141(1):2-18. https:// doi.org/10.1037/a0026092

23. Cohen J. Statistical power analysis for the behavioral sciences. New York: Routledge; 1988.

24. Nguyen T, Bang DD, Wolff A. 2019 novel coronavirus disease (covid-19): paving the road for rapid detection and point-of-care diagnostics. Micromach (Basel). 2020;11(3):306. https://doi.org/10.3390/mi11030306

25. Huang Y, Zhao N. Generalized anxiety disorder, depressive symptoms and sleep quality during covid-19 outbreak in China: a web-based cross-sectional survey. Psychiatry Res. 2020;288:112954. https://doi.org/10.1016/j.psychres.2020.112954

26. Sandín B, Valiente RM, García-Escalera J, Chorot P. Impacto psicológico de la pandemia de covid-19: efectos negativos y positivos en población española asociados al periodo de confinamiento nacional. Rev Psicopatol Psicol Clin. 2020;25(1):1-22. https://doi.org/10.5944/ rppc.27569

27. Organização Pan-Americana da Saúde. Devastadoramente generalizada: 1 em cada 3 mulheres em todo o mundo sofre violência [Internet]. Brasília, DF: OPAS; 2021 [cited 2021 Apr 22]. Available from: https://www.paho.org/pt/ noticias/9-3-2021-devastadoramente-generalizada-1-em-cada-3-mulheres-em-todo-mundo-sofre-violencia

28. Perz CA, Lang BA, Harrington R. Validation of the fear of covid-19 scale in a US college sample. Int J Ment Health Addict. 2020;1-11. https:// doi.org/10.1007/s11469-020-00356-3

29. Robles TF, Slatcher RB, Trombello JM, McGinn MM. Marital quality and health: a meta-analytic review. Psychol Bull. 2014;140(1):140-87. https://doi.org/10.1037/a0031859

30. Kiecolt-Glaser JK, Wilson SJ. Lovesick: how couples' relationships influence health. Annu Rev Clin Psychol. 2017;13:421-43. https://doi. org/10.1146/annurev-clinpsy-032816-045111

31. Paveltchuk FO, Borsa JC. A teoria do estresse de minoria em lésbicas, gays e bissexuais. Rev SPAGESP [Internet]. 2020[cited 2021 Mar 14];21(2):41-54. Available from: http://pepsic.bvsalud.org/scielo.php?script=sci_arttext\&pid=S1677-29702020000200004\&lng=pt

32. Bordiano G, Liberal SP, Lovisi GM, Abelha L. Covid-19, vulnerabilidade social e saúde mental das populações LGBTQIA+. Cad Saude Publica. 2021;37(3). https://doi.org/10.1590/0102-311X00287220

33. Haddad C, Malhab SB, Sacre H, Salameh P. Smoking and covid-19: a scoping review. Tob Use Insights. 2021:14:1179173X21994612. https:// doi.org/10.1177/1179173X21994612

34. Nasser AMA, Zhang X. Knowledge and factors related to smoking among university students at Hodeidah university, Yemen. Tob Induc Dis. 2019;17:42. https://doi.org/10.18332/tid/109227

35. Marelli S, Castelnuovo A, Somma A, Castronovo V, Mombelli S, Bottoni D, et al. Impact of COVID-19 lockdown on sleep quality in university students and administration staff. J Neurol. 2021; 268(1):8-15. https://doi.org/10.1007/s00415-020-10056-6

36. Xiao H, Zhang Y, Kong D, Li S, Yang N. Social capital and sleep quality in individuals who self-isolated for 14 days during the coronavirus disease 2019 (covid-19) outbreak in january 2020 in China. Med Sci Monit. 2020;26:e923921. https://doi.org/10.12659/MSM.923921

37. Lin C-Y, Broström A, Griffiths MD, Pakpour AH. Investigating mediated effects of fear of covid-19 and covid-19 misunderstanding in the association between problematic social media use, psychological distress, and insomnia. Internet Interv. 2020;21:100345. https://doi. org/10.1016/j.invent.2020.100345

38. Salmani AAA, Shidhani AA, Qassabi SSA, Yaaribi SAA, Musharfi AMA. Prevalence of sleep disorders among university students and its impact on academic performance. Int J Adolesc Youth. 2020;25(1):974-81. https://doi.org/10.1080/02673843.2020.1815550

39. Harper CA, Satchell LP, Fido D, Latzman, RD. Functional fear predicts public health compliance in the covid-19 pandemic. Int J Ment Health Addict. 2020:1-14. https://doi.org/10.1007/s11469-020-00281-5

40. Musche V, Kohler H, Bäuerle A, Schweda A, Weismüller B, Fink M, et al. Covid-19-related fear, risk perception, and safety behavior in individuals with diabetes. Healthcare (Basel). 2021;9(4):480. https://doi.org/10.3390/healthcare 9040480 
41. Holman EA, Garfin DR, Silver RC. Media's role in broadcasting acute stress following the Boston marathon bombings. Proc Natl Acad Sci USA. 2014;111(1):93-8. https://doi.org/10.1073/pnas.1316265110

42. Van den Bulck J, Custers K. Television exposure is related to fear of avian flu, an Ecological Study across 23 member states of the European Union. Eur J Public Health. 2009;19(4):370-4. https://doi.org/10.1093/eurpub/ckp061

43. Garcia LP, Duarte E. Infodemia: excesso de quantidade em detrimento da qualidade das informações sobre a covid-19. Epidemiol Serv Saude. 2020;29(4):e2020186. https://doi.org/10.1590/S1679-49742020000400019 